\title{
DIET-DERIVED VARIATIONS IN RADIOCARBON AND STABLE ISOTOPES: A CASE STUDY FROM SHAG RIVER MOUTH, NEW ZEALAND
}

\author{
Thomas Higham $^{1} \bullet$ Atholl Anderson ${ }^{2}$ Christopher Bronk Ramsey ${ }^{1}$ Christine Tompkins $^{1}$ \\ ABSTRACT. Accelerator mass spectrometry (AMS) determinations of rat bones from natural and cultural sites in New \\ Zealand have produced ages at odds with the accepted date for early human settlement by over $1000 \mathrm{yr}$. Since rats are a human \\ commensal, this implies either an earlier visitation by people or problems with the reliability of the AMS determinations. One \\ explanation for the extreme ages is dietary variation involving movement of depleted radiocarbon through dietary food chains \\ to rats. To investigate this, we ${ }^{14} \mathrm{C}$ dated fauna from the previously well-dated site of Shag River Mouth. The faunal remains \\ were of species that consumed carbon derived from a variety of environments within the orbit of the site, including the estu- \\ ary, river, land, and sea. The ${ }^{14} \mathrm{C}$ results showed a wide range in age among estuarine and freshwater species. Terrestrial and \\ marine organisms produced ages within expectations. We also found differences between bone dated using the Oxford ultra- \\ filtration method and those treated using the filtered gelatin method. This implies that contamination could also be of greater \\ importance than previously thought.
}

\section{INTRODUCTION}

Variation in the uptake of dietary protein among omnivorous species is often linked with radiocarbon reservoir effects, and the study of paleodiet is becoming an increasingly important adjunct to the field of bone accelerator mass spectrometry (AMS) ${ }^{14} \mathrm{C}$ dating (Lanting and van der Plicht 1998; Cook et al. 2001; Bonsall et al. 2004). AMS ${ }^{14} \mathrm{C}$ dates of omnivorous terrestrial organisms, such as humans, dogs, rats, and pigs, may be prone to offsets from "true age" if careful attention is not paid to potential ${ }^{14} \mathrm{C}$ reservoir variation. In some contexts, these reservoir offsets, if they can be shown to exist, can be significant (Bonsall et al. 2004).

\section{RAT BONE DATING AND HUMAN ARRIVAL}

AMS ${ }^{14} \mathrm{C}$ dates of Rattus exulans bone from New Zealand are relevant for dating human presence because rats were vectored by people across the Pacific (Holdaway 1996). The results of these measurements are controversial because some date about $1300 \mathrm{yr}$ earlier than the first dated evidence for human settlement as shown in the archaeological record (Anderson 1991; Higham and Hogg 1997; Higham et al. 1999). To check whether AMS dates obtained from archaeological rat bones are reliable, bones from secure contexts within previously dated archaeological sites have been analyzed. The results have largely been poor (see Anderson 1996, 2000; Beavan Athfield et al. 1999; Higham and Petchey 2000). The Kokohuia site, in Northland, initially produced rat bone determinations some $1200 \mathrm{yr}$ too old. This was later shown to be the result of a contaminant derived from ultrafilters used in the bone pretreatment process (Higham et al. 2004a). Subsequent reanalyses showed no offsets between rat bone and other materials. The Pleasant River and Shag River Mouth sites both produced rat bone dates that were offset by up to $1200 \mathrm{yr}$ from other materials (Anderson 1996; Smith and Anderson 1998). Higham et al. (2004b) were unable to duplicate the early series reported by Anderson (1996). They showed that contamination at the Shag River site was present in some of the bones but was not in sufficient proportion to shift ${ }^{14} \mathrm{C}$ ages by the degree required. Similarly, Beavan-Athfield and Sparks (2001b) found that contaminants at Pleasant River were of similar ${ }^{14} \mathrm{C}$ age to the archaeological materials themselves. Anderson (2004) identified an "age disconformity" in the main assemblage of rat bone dates, both natural and archaeological; ${ }^{14} \mathrm{C}$ determinations from

${ }^{1}$ Oxford Radiocarbon Accelerator Unit, Research Laboratory for Archaeology and the History of Art, University of Oxford, Oxford OX1 3QJ, United Kingdom.

${ }^{2}$ Department of Archaeology and Natural History, Research School of Pacific and Asian Studies, Australian National University, Canberra ACT 0200, Australia. 
both site types fall into the same age ranges when plotted against the period of processing in the Rafter Radiocarbon Laboratory, IGNS, which suggests an underlying laboratory problem, possibly in pretreatment.

One aspect of the rat bone dating problem that remains poorly known is the influence of dietary carbon. Beavan-Athfield and Sparks (2001a) suggested that a dietary effect might explain the erroneous rat bone determinations at Pleasant River. They dated samples of bone from 7 species of terrestrial, marshland, and marine birds from archaeological contexts at the site. These included the terrestrial feeders, New Zealand quail (Coturnix novaezealandiae) and parakeet (Cyanoramphus sp.); the omnivorous marshland species, New Zealand shoveller duck (Anas rynchotis), grey duck (Anas superciliosa), and brown teal (Anas antipodes); the marine yellow-eyed penguin (Megadyptes antipodes); and the estuarine/marine spotted shag (Stictocarbo punctatus). The species were chosen to investigate variability in dietary sources and their potential effect on ${ }^{14} \mathrm{C}$ ages. The results suggested that there were offsets between the ages of the omnivorous marshland birds compared with the age established for the site based on reliable terrestrial substrates (e.g. charcoal, identified and short-lived in age). The offset of $\sim 230 \mathrm{yr}$ was less than the marine reservoir offset, which in New Zealand surface waters is about $385 \mathrm{yr}(\Delta \mathrm{R}=-11 \pm 12 \mathrm{yr}$ : Reimer and Reimer 2001) but was nevertheless significant. Despite the lack of any marine isotope signatures in any of the dated bones, Beavan-Athfield and Sparks (2001a) suggested that a partial reservoir correction was applicable. This correction was applied to aquatic/marshland organisms and to the rat bones previously determined. Some of the results fell within the established age of the site, but others remained either much too old or much too young. The reason for this, according to Beavan-Athfield and Sparks (2001a), is that some of the rats may not have fed on any depleted ${ }^{14} \mathrm{C}$ source, while others may have. The reliability of rat bone for ${ }^{14} \mathrm{C}$ dating here is obviously limited under these circumstances, yet the possibility that bone from natural sites might be similarly affected has not hindered the development of models that are based upon taking rat bone determinations at face value (e.g. Holdaway 1999). The crucial question here, therefore, is to what extent might potential food items of Rattus exulans have been subject to dietary offsets in ${ }^{14} \mathrm{C}$ age.

In this paper, we present a case study from the nearby site of Shag River Mouth in order to investigate this issue.

\section{THE SHAG RIVER MOUTH SITE}

The archaeological sequence at the Shag River Mouth site is described in Anderson et al.'s (1996a) detailed report. Prehistoric evidence covering about 2 ha has been identified at the edge of the nearby estuary and within the adjacent Salicornia-dominated mud flats (Figure 1). A wide faunal spectrum included marine and terrestrial fauna. The artifactual material recovered is typical of the late Archaic phase of New Zealand culture. The most extensive excavation undertaken at the site took place in 1988 where a $10 \times 10-\mathrm{m}$ square was opened on the highest part of the dune (SM/C: Dune). The material described in this paper comes from this area (Anderson et al. 1996a).

Over $60{ }^{14} \mathrm{C}$ determinations from the site (Anderson et al. 1996b) show that occupation began in the 14 th century AD and lasted for perhaps $40-50 \mathrm{yr}$ at most. Dating material from these archaeological contexts therefore provides a reliable basis for comparison with a known age.

\section{METHOD}

We obtained 24 samples of bird bones from a variety of species and a diverse range of environments in Layer 4 and Layer 5 (Table 1). The bones were of individual elements from secure contexts. We 


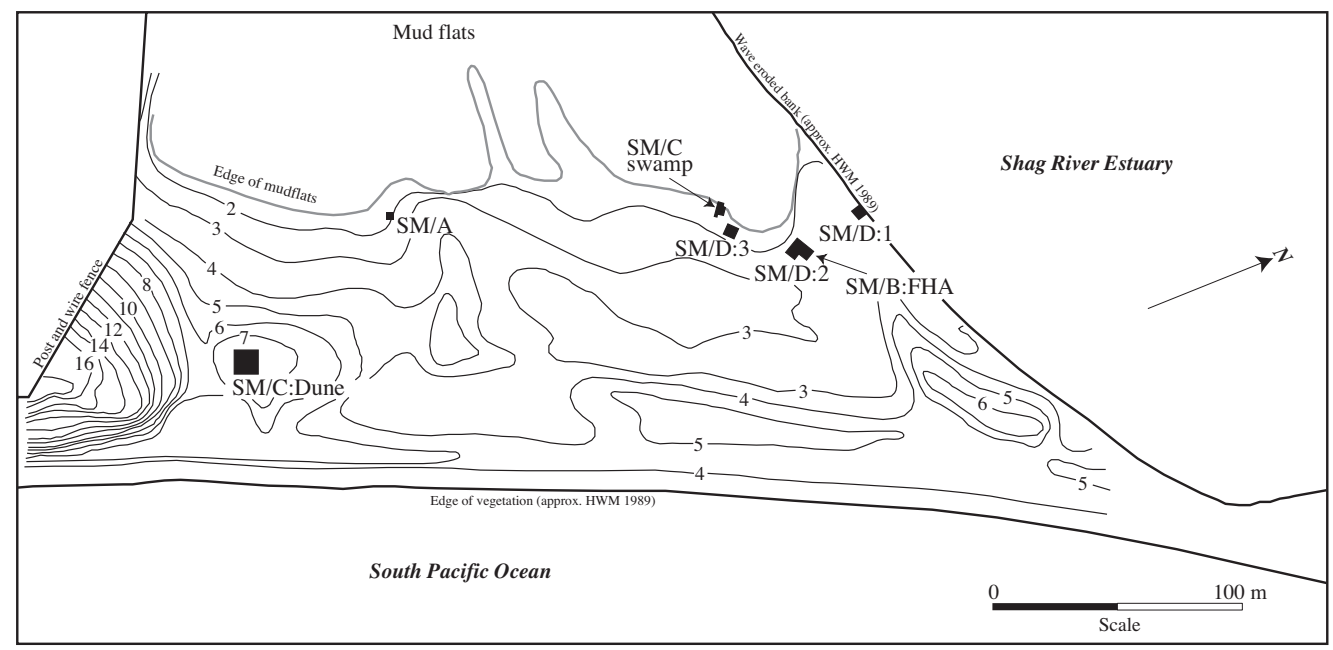

Figure 1 Location of excavated areas at the Shag River Mouth site, New Zealand. Material described in this paper comes from the SM/C:Dune area.

also obtained 5 further elements of Rattus exulans bone from Layer 4 (Table 2). Rat bone is a particularly challenging material to AMS date because of the extremely small size of the individual elements (Table 3). The bones were pretreated to remove surficial soil and detritus with a scalpel and an aluminium oxide shotblaster. They were then powdered using a mortar and pestle and weighed. Each bone was manually pretreated initially with decalcification using $0.5 \mathrm{M} \mathrm{HCl}$, removal of humates using $0.1 \mathrm{M} \mathrm{NaOH}$, and then re-acidification using $0.5 \mathrm{M} \mathrm{HCl}$. Each step was interspersed with distilled water rinses. The samples were gelatinized in weakly acidic water $(\mathrm{pH} 3)$ at $75^{\circ} \mathrm{C}$ in an incubator for $20 \mathrm{hr}$, and the supernatant was recovered using an EziFilter ${ }^{\mathrm{TM}}$ and lyophilized. These gelatin samples are denoted in Table 3 by the code "AG." In all other cases, the supernatant was further treated by ultrafiltration using a Vivaspin ${ }^{\mathrm{TM}} 30-\mathrm{kD}$ MWCO ultrafilter. The $>30-\mathrm{kD}$ fraction was lyophilized and retained for AMS dating (Table 1). These samples of ultrafiltered gelatin are denoted by the prefix "AF" in Table 3. This is the usual (and more rigorous) ORAU pretreatment. The ultrafilter removes low-molecular weight particles, including degraded and broken-up collagen fragments, soil particulate matter, and non-collagenous contaminants. In one instance, we obtained a very low yield of "collagen" 1 from a single rat bone element, and this was subjected to no additional pretreatment (P11854, code NRC in Table 2).

Samples of bone gelatin were combusted and analyzed using an Europa Scientific ANCA-MS system consisting of a 20-20 IR mass spectrometer interfaced to a Roboprep CHN sample converter unit operating in continuous flow mode using an He carrier gas. This enables the measurement of $\delta^{15} \mathrm{~N}$ and $\delta^{13} \mathrm{C}$, nitrogen and carbon content, and C:N ratios. $\delta^{13} \mathrm{C}$ values in this paper are reported with reference to VPDB, and $\delta^{15} \mathrm{~N}$ results are reported with reference to AIR (Coplen 1994). Graphite was prepared by reduction of $\mathrm{CO}_{2}$ over an iron catalyst in an excess $\mathrm{H}_{2}$ atmosphere at $560{ }^{\circ} \mathrm{C}$ prior to AMS ${ }^{14} \mathrm{C}$ measurement (Bronk Ramsey and Hedges 1999; Bronk Ramsey et al. 2000). Smaller samples $(<1.6-0.5 \mathrm{mg} \mathrm{C})$ were AMS dated using the Oxford $\mathrm{CO}_{2}$ gas ion source. The Oxford AMS ${ }^{14} \mathrm{C}$ method and instrumentation is reported by Bronk Ramsey and Hedges (1999), Bronk Ramsey et al. (2000), and Bronk Ramsey et al. (2004).

${ }^{1}$ We follow DeNiro and Weiner (1988) and van Klinken (1999) in using quotation marks to distinguish this from strictly biologically defined collagen. 
Table 1 Samples of bird bone obtained for this study.

\begin{tabular}{|c|c|c|c|c|c|}
\hline P number & $\begin{array}{l}\text { Sample } \\
\text { reference }\end{array}$ & Lyr. & Sq. & Species & Element \\
\hline 11830 & BB0196 & 4 & $\mathrm{I} 2$ & $\begin{array}{l}\text { NZ pigeon } \\
\text { (Hemiphaga novaeseelandiae) }\end{array}$ & Ulna \\
\hline 11831 & BB0199 & 4 & I4 & NZ pigeon (H. novaeseelandiae) & Femur \\
\hline 11832 & BB0556 & 4 & G-H8 & NZ pigeon (H. novaeseelandiae) & L. humerus \\
\hline 11833 & BB0556 & 4 & G-H8 & NZ pigeon (H. novaeseelandiae) & L. coracoid \\
\hline 11834 & BB0559 & 4 & H5 & NZ pigeon (H. novaeseelandiae) & R. tibiotarsus \\
\hline 11835 & BB0228 & 4 & I8 & Shy mollymawk (Diomedea cauta) & L. humerus \\
\hline 11836 & BB0227 & 4 & $\mathrm{~J} 1$ & Shy mollymawk (D. cauta) & R. tarsometatarsal \\
\hline 11837 & BB0238 & 4 & $\mathrm{~J} 2$ & Shy mollymawk (D. cauta) & R. tibiotarsus \\
\hline 11838 & BB0261 & 4 & J8 & Shy mollymawk (D. cauta) & R. tarsometatarsal \\
\hline 11839 & BB0610 & 4 & $\mathrm{~J} 8$ & Shy mollymawk (D. cauta) & L. carpometacarpus \\
\hline 11840 & BB0125 & 4 & E8 & Blue penguin (Eudyptula minor) & L. humerus \\
\hline 11841 & BB0205 & 4 & I5 & Blue penguin $($ E. minor $)$ & L. femur \\
\hline 11842 & BB0215 & 4 & $\mathrm{I} 7$ & Blue penguin (E. minor) & L. coracoid \\
\hline 11843 & BB0253 & 4 & $\mathrm{~J} 7$ & Blue penguin (E. minor) & Sacrum \\
\hline 11844 & BB0599 & 4 & $\mathrm{~J} 6$ & Blue penguin (E. minor) & L. tibiotarsus \\
\hline 11845 & BВ0139 & 4 & F7 & $\begin{array}{l}\text { Grey teal/Brown teal } \\
\text { (Anas gracilis/Anas chlorotis) }\end{array}$ & L. coracoid \\
\hline 11846 & BB0265 & 4 & $\mathrm{~J} 8$ & Grey duck (Anas superciliosa) & Sternum \\
\hline 11847 & BB0266 & 4 & $\mathrm{~J} 8$ & Grey duck (A. superciliosa) & L. ulna \\
\hline 11848 & BB0533 & 4 & B8 & Brown teal (A. chlorotis) & L. humerus \\
\hline 11849 & BB0552 & 4 & G8 & $\begin{array}{l}\text { NZ shoveller or Brown teal } \\
\text { (Anas rhynchotis/A. chloroticus) }\end{array}$ & R. coracoid \\
\hline 11850 & BВ0269 & 5 & A1 & NZ pigeon (H. novaeseelandiae) & R. humerus \\
\hline 11851 & BB0293 & 5 & B8 & Shy mollymawk (D. cauta) & L. ramus \\
\hline 11852 & BB0277 & 5 & A6 & Blue penguin (E. minor) & R. femur \\
\hline 11853 & BB0306 & 5 & D1 & Grey duck (A. superciliosa) & L. coracoid \\
\hline
\end{tabular}

Table 2 Samples of rat bone obtained for this study; all are from Layer 4 at the SM/C area of the site.

\begin{tabular}{llll}
\hline P number & Sample reference & Element & Side \\
\hline 11854 & SM/C:Layer 4 Br144-01 & humerus & $\mathrm{R}$ \\
11855 & SM/C:Layer 4 Br149-01 & femur & $\mathrm{L}$ \\
11856 & $\mathrm{SM}$ /C:Layer 4 Br016-01 & humerus & $\mathrm{R}$ \\
11857 & $\mathrm{SM}$ /C:Layer 4 Br074-02 & humerus & $\mathrm{R}$ \\
11858 & $\mathrm{SM}$ /C:Layer 4 Br070-05 & femur & $\mathrm{R}$ \\
\hline
\end{tabular}

\section{RESULTS AND DISCUSSION}

The ${ }^{14} \mathrm{C}$ results are given in Table 3 . There is a consistent pattern in the AMS results of carnivorous marine birds (mollymawk and penguin). These organisms obtain all of their dietary protein from the ocean and therefore can be assumed to be subject to the local marine reservoir effect. We corrected the results using the marine $\Delta \mathrm{R}$ value for New Zealand of $-11 \pm 12 \mathrm{yr}$ (Reimer and Reimer 2001: www.calib.org) with the IntCal98 modeled marine curve (Stuiver et al. 1998). These calibrated dates show good agreement with the expected age of the site (Figure 2). Results for the determinations 
Table 3 AMS ${ }^{14} \mathrm{C}$ dates and associated analytical data for the bones described in this paper. The pretreatment code AF refers to ultrafiltrated gelatin; the code AG refers to filtered gelatin and the NRC code refers to collagen (see text for details). Stable isotope ratios are expressed relative to VPDB and nitrogen to AIR. Machine precision is \pm 0.2 for carbon and \pm 0.3 for nitrogen. Collagen yields and starting weights are expressed in milligrams. AG yields represent aliquots taken from the whole gelatin prior to ultrafiltering the remaining material.

\begin{tabular}{llllllllllll}
\hline & \multicolumn{1}{c}{$\begin{array}{l}{ }^{14} \mathrm{C} \text { age } \\
\text { Species }\end{array}$} & P no. & P code & OxA & \multicolumn{1}{c}{ BP } & Error & CN & $\delta^{13} \mathrm{C}$ & $\delta^{15} \mathrm{~N}$ & \multicolumn{1}{c}{ Start } & \multicolumn{1}{c}{ Coll. } \\
yield & $\% \mathrm{C}$ \\
\hline NZ pigeon & 11830 & AF & 12829 & 617 & 25 & 3.2 & -20.4 & 5.6 & 260 & 29.8 & 42.1 \\
& 11831 & AF & 12830 & 572 & 24 & 3.2 & -20.8 & 5.2 & 210 & 36.4 & 42.3 \\
& 11832 & AG & $1051-15$ & 734 & 39 & 3.3 & -20.0 & 5.5 & na & 5.2 & 45.3 \\
& 11832 & AF & 13239 & 523 & 23 & 3.2 & -20.7 & 5.3 & 480 & 37.0 & 43.7 \\
& 11850 & AG & $1051-24$ & 721 & 39 & 3.3 & -19.4 & 4.8 & 5.7 & 5.7 & 42.8 \\
\hline Shy & 11835 & AG & $1051-18$ & 1240 & 40 & 3.3 & -14.6 & 17.5 & na & 5.0 & 43.7 \\
mollymawk & 11835 & AF & 13240 & 1058 & 23 & 3.1 & -13.0 & 18.0 & 560 & 58.3 & 43.7 \\
& 11836 & AF & 12831 & 1063 & 24 & 3.2 & -11.9 & 18.7 & 300 & 33.9 & 41.7 \\
& 11837 & AF & 12832 & 1090 & 25 & 3.2 & -13.8 & 15.7 & 350 & 61.0 & 42.0 \\
& 11838 & AF & 12833 & 1062 & 25 & 3.2 & -11.4 & 18.9 & 280 & 21.1 & 42.3 \\
\hline Blue & 11840 & AF & 13093 & 1001 & 27 & 3.3 & -13.7 & 15.8 & 420 & 27.7 & 42.6 \\
penguin & 11841 & AF & 12834 & 1035 & 24 & 3.2 & -13.7 & 15.8 & 480 & 35.8 & 43.0 \\
& 11842 & AF & 12835 & 992 & 24 & 3.2 & -13.8 & 14.8 & 440 & 36.0 & 42.8 \\
\hline Shoveller/ & 11845 & AF & 13094 & 1414 & 29 & 3.3 & -16.6 & 15.5 & 280 & 31.6 & 42.4 \\
Brown teal & & & & & & & & & & & \\
Grey duck & 11846 & AF & 13095 & 847 & 28 & 3.3 & -14.0 & 11.9 & 460 & 60.8 & 41.6 \\
Grey duck & 11847 & AF & 12836 & 785 & 26 & 3.2 & -18.8 & 7.5 & 220 & 11.7 & 42.5 \\
Brown teal & 11848 & AF & 13096 & 984 & 27 & 3.3 & -15.7 & 11.7 & 420 & 45.7 & 42.2 \\
Grey duck & 11853 & AF & 12837 & 669 & 26 & 3.2 & -19.0 & 14.2 & 500 & 18.4 & 43.8 \\
\hline Pacific rat & 11854 & NRC & $1053-05$ & 840 & 40 & 3.6 & -22.1 & 13.4 & 19.5 & 1.8 & 43.3 \\
& 11855 & AG & 13371 & 530 & 45 & 3.3 & -20.5 & 15.8 & 50 & 7.0 & 42.2 \\
& 11858 & AF & $2075-16$ & 715 & 40 & 3.4 & -19.5 & 21.0 & 101.6 & 5.9 & 41.9 \\
& 11858 & AG & 13372 & 475 & 50 & 3.3 & -19.4 & 21.0 & na & 12.8 & 42.4 \\
\hline
\end{tabular}

obtained for the New Zealand pigeon yielded similarly acceptable results. These birds consume a predominantly terrestrial plant diet; therefore, their ages would be expected to be in equilibrium with atmospheric ${ }^{14} \mathrm{C}$. All of the ultrafiltered gelatin results were in expected agreement with the age of the site as described above.

We dated one pigeon bone twice (P11832) with different pretreatments applied (filtered gelatin; OxA-X-1051-15 and ultrafiltered gelatin; OxA-13239). We also dated a shy mollymawk bone (P11835) twice, again with these pretreatments applied. The results were significantly different, with the dates of ultrafiltered gelatin both younger than the gelatin fraction. In the case of the mollymawk bone, the ultrafiltered determination was in excellent agreement with the other 4 dated specimens, whereas the gelatinized sample was over $200 \mathrm{yr}$ too old. These results imply small amounts of older contaminants incorporated in the bone, with the ultrafilters removing low-molecular weight material of a different ${ }^{14} \mathrm{C}$ age. Our recent experience suggests that ultrafiltered bone determinations are more reliable than non-ultrafiltered determinations (Bronk Ramsey et al. 2004; Stuart et al. 2004). A deal of complexity is attested to by 2 dates of rat bone (P11858), again pretreated using both methods but with the ultrafiltered sample producing an older result. Higham et al. (2004b) also found that there were small amounts of contaminants in the bone dated, with gelatin 


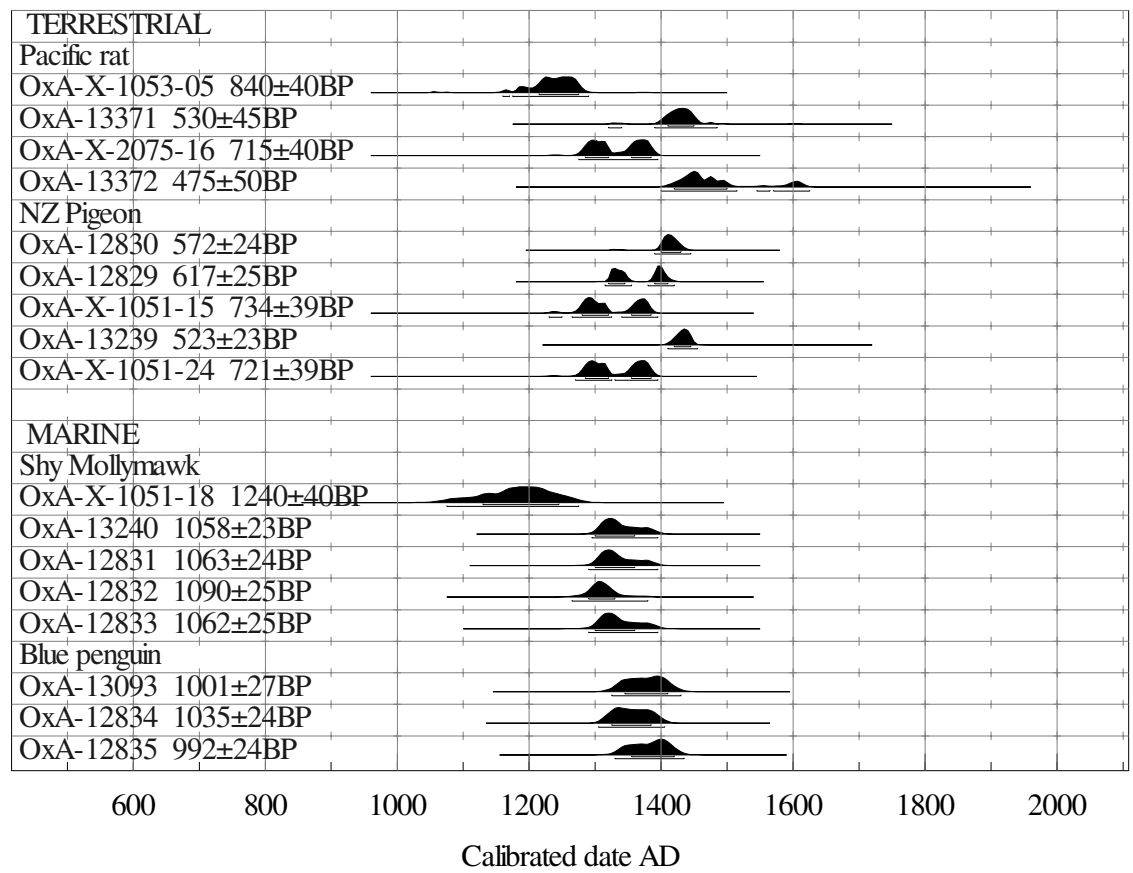

Figure 2 Calibrated age ranges for Shag River Mouth fauna. The terrestrial samples were calibrated using the Southern Hemisphere calibration curve (McCormac et al. 2002) with OxCal (Bronk Ramsey 2001). The marine samples were calibrated using the modeled marine curve of IntCal98 (Stuiver et al. 1998). The age of the Shag River Mouth site, based upon extensive ${ }^{14} \mathrm{C}$ dating, is 14 th century AD (Anderson et al. 1996b). Actual calibrated ranges are shown in Table 4.

dates generally younger than raw "collagen" dates, but in almost every case these were not statistically significant. However, due to the small size of the elements they dated and uncertainty about the most effective removal of humectants coating the ultrafilters (see Bronk Ramsey et al. 2004), they were not able to pretreat bones using this more rigorous method. The fact that the ultrafiltered dates reported here were different than their paired gelatin equivalent suggests that pretreatment methodology could, in fact, be important in accurately AMS dating rat bone from New Zealand contexts.

Once again, the Rattus exulans bone we dated produced ${ }^{14} \mathrm{C}$ results that were variable but in reasonable agreement with previous determinations. The stable carbon isotope values provide evidence for a terrestrial diet, although, as Beavan-Athfield and Sparks (2001a) have argued, this cannot necessarily be accepted as equating to reliable ${ }^{14} \mathrm{C}$ results given the possibility of depleted ${ }^{14} \mathrm{C}$ becoming fixed at the base of local food chains via photosynthetic processes within the estuary. The $\delta^{15} \mathrm{~N}$ values associated with the P11858 determinations are highly enriched and imply a high trophic level carnivore, or, given the lack of a marine signature in the $\delta^{13} \mathrm{C}$ value, a dietary influence derived from freshwater environs (cf. Beavan-Athfield and Sparks 2001a). Further research is required.

Results for estuarine and freshwater duck bones produced a wide range in ages. Beavan-Athfield and Sparks (2001a) showed that these organisms could uptake carbon of varying ${ }^{14} \mathrm{C}$ age in particular environments in New Zealand. They found an offset in the ages of about $230 \mathrm{yr}$, with the ducks older when compared with other dated materials of terrestrial origin. We have found a similar pattern, but with greater variation, in the size of the offset from the age of the site. One example is worthy of particular mention. The ${ }^{14} \mathrm{C}$ age of OxA-13094 was a bone identified as shoveller/brown 
Table 4 Calibrated age ranges for samples of bone dated in this paper.

\begin{tabular}{lll}
\hline & $\begin{array}{l}\text { Calibrated age range (years AD) } \\
\text { OxA number }\end{array}$ & $\begin{array}{l}\text { Calibrated age range (years AD) } \\
95.4 \% \text { probability }\end{array}$ \\
\hline OxA-X-1053-05 & $1215-1275(68.2 \%)$ & $1160-1170(1.5 \%)$ \\
OxA-13371 & $1410-1450(68.2 \%)$ & $1175-1290(93.9 \%)$ \\
& & $1320-1340(2.2 \%)$ \\
OxA-X-2075-16 & $1285-1320(35.0 \%)$ & $1390-1485(93.2 \%)$ \\
& $1355-1385(33.2 \%)$ & $1275-1395(95.4 \%)$ \\
OxA-13372 & $1420-1500(68.2 \%)$ & $1400-1515(78.5 \%)$ \\
& & $1545-1565(1.9 \%)$ \\
OxA-12830 & $1400-1430(68.2 \%)$ & $1570-1625(15.0 \%)$ \\
OxA-12829 & $1320-1345(37.8 \%)$ & $1390-1445(95.4 \%)$ \\
& $1390-1410(30.4 \%)$ & $1315-1355(50.5 \%)$ \\
OxA-X-1051-15 & $1280-1320(41.1 \%)$ & $1380-1420(44.9 \%)$ \\
& $1355-1385(27.1 \%)$ & $1230-1250(2.2 \%)$ \\
OxA-13239 & $1420-1445(68.2 \%)$ & $1340-1395(42.9 \%)$ \\
OxA-X-1051-24 & $1285-1320(37.3 \%)$ & $1410-1455(95.4 \%)$ \\
& $1355-1385(30.9 \%)$ & $1270-1325(48.6 \%)$ \\
OxA-X-1051-18 & $1130-1245(68.2 \%)$ & $1330-1395(46.8 \%)$ \\
OxA-13240 & $1300-1360(68.2 \%)$ & $1075-1275(95.4 \%)$ \\
OxA-12831 & $1300-1360(68.2 \%)$ & $1295-1395(95.4 \%)$ \\
OxA-12832 & $1290-1330(68.2 \%)$ & $1290-1395(95.4 \%)$ \\
OxA-12833 & $1300-1360(68.2 \%)$ & $1265-1380(95.4 \%)$ \\
OxA-13093 & $1345-1410(68.2 \%)$ & $1325-1430(95.4 \%)$ \\
OxA-12834 & $1325-1385(68.2 \%)$ & $1305-1405(95.4 \%)$ \\
OxA-12835 & $1355-1420(68.2 \%)$ & $1330-1435(95.4 \%)$ \\
\hline
\end{tabular}

teal. It produced a ${ }^{14} \mathrm{C}$ age of $1414 \pm 29 \mathrm{BP}$, which is substantially older than expected. At least 2 possible explanations must be considered. First, the bone may have been deposited prior to human occupation of the site and became incorporated in it subsequently. Second, there are older carbon sources than expected being taken up within dietary foodwebs originating in the Shag River estuary. We think the latter possibility is more likely because the excavation of the SM/C:Dune area of the site disclosed no substantial post-depositional reworking. Layer 4, the stratum from which the bone originated, was well preserved and not subject to mixing. The possibility that there is older labeled ${ }^{14} \mathrm{C}$ within the estuary might mean that omnivores higher on the food chain could uptake this, passing on a depleted ${ }^{14} \mathrm{C}$ signal. This is an avenue of considerable importance for further research.

As mentioned above, Beavan-Athfield and Sparks (2001a) found that there was no convincing stable isotope evidence for a significant marine contribution to the diets of the estuarine and freshwater duck bones analyzed at Pleasant River. Our results show carbon isotope enrichments with associated offsets in age for 3 of the 5 specimens. For the 2 other specimens, the $\delta^{13} \mathrm{C}$ values were about $-19 \%$, and the offset from true age was much less. Beavan-Athfield and Sparks (2001a) analyzed bone from the shoveller duck and obtained a $\delta^{13} \mathrm{C}$ value for the bone collagen of $-27.7 \%$. This is very depleted and again implies a varying degree of carbon sourcing within the estuary. Taking the 2 sets of data together, the picture is one of great variability for all 3 isotope measurements of freshwater and estuarine species. 
There are additional reservoir offsets in this region that differ from the marine reservoir. ${ }^{14} \mathrm{C}$ measurements of the mudsnail Amphibola crenata, from Shag River and other sites, for instance, have produced aberrant results. Amphibola inhabit $\mathrm{O}_{2}$-depleted areas at the very highest tidal margins, near salt swamps or mangroves, where there is fine organic mud to process. The organic component here, and that of the tidal inflow, are their principal food sources. Experiments have shown that Amphibola survive for less than 6-7 days in freshwater and 10-18 days in seawater before dying. The reason is that they are an archaic pulmonate, at a mid-point in gastropod evolution, preferring to obtain atmospheric $\mathrm{O}_{2}$ rather than extract it from the water through gills (Morton and Miller 1968). Variation in the ${ }^{14} \mathrm{C}$ concentrations of this organism may be caused by the gastropod processing fine organic muds of an older ${ }^{14} \mathrm{C}$ activity, giving them apparent ages in comparison to other bivalves such as Austrovenus that are, by contrast, filter-feeding organisms. At the Pleasant River site, ${ }^{14} \mathrm{C}$ dates of Amphibola were older than other samples in direct association. Wk-2507 on Amphibola, for example, produced a date of $1140 \pm 45 \mathrm{BP}$, while Wk-2753 (910 $\pm 50 \mathrm{BP})$ on Austrovenus stutchburyi was obtained from the same context (Higham 1993). An older than expected determination (NZ-4436) from Pleasant River yielded a date of $1120 \pm 26$ BP (Anderson 1991). At Shag Mouth, Wk-2367 (1160 $\pm 50 \mathrm{BP})$ was only slightly older than Wk-2368 (1080 $\pm 50 \mathrm{BP})$, a determination of Paphies australis (Higham 1993; Anderson et al. 1996b).

\section{CONCLUSIONS}

Our results show that potentially large reservoir offsets may be associated with different fauna at the Shag River Mouth site in New Zealand. Although the marine and terrestrial fauna we AMS dated produced ages that were within expectations after reservoir correction, results of estuarine/freshwater fauna were anomalous. The transfer of non-equilibrium carbon through food chains appears to be supported by determinations of foraging duck species, as well as deposit-feeding shellfish. Our ${ }^{14} \mathrm{C}$ results for ducks were variable and all too old, with one ${ }^{14} \mathrm{C}$ result substantially older than the accepted archaeological age. In all cases but one, the offset broadly correlated with enriched nitrogen stable isotope values as suggested by Higham et al. (2004b). At this stage, we are left with the tantalizing possibility that some of the rat bone determinations initially dated and listed in Anderson (1996) were too old by virtue of a dietary reservoir effect. Further work is required to investigate the degree of variation. It is worth bearing in mind that none of the determinations of rat bone produced at ORAU have yet resulted in ages greater than 1000 BP. In addition, we have identified the removal of older carbon using ultrafiltration, a technique not applied to bone from this context before. This suggests that pretreatment methodologies may have a more significant influence on accurate dating than previously thought, and that dietary variation may not be the sole causative factor.

Crucially, attention must be turned to stable and radioisotope variations in the environs of the natural sites that provided the initial suite of old rat bone results (Holdaway 1996, 1999) upon which the model of early rat colonization has been advanced.

\section{ACKNOWLEDGMENTS}

We acknowledge with gratitude the staff of the Oxford Radiocarbon Accelerator Unit at the University of Oxford for their careful laboratory assistance, particularly A Bowles, D Baker, J Foreman, M Humm, H Kjeldsen, P Leach, C Owen, and C Sykes.

\section{REFERENCES}

Anderson AJ. 1991. The chronology of colonisation in New Zealand. Antiquity 65:767-95.

Anderson AJ. 1996. Was Rattus exulans in New Zealand

2000 years ago? AMS radiocarbon ages from Shag River Mouth. Archaeology in Oceania 31:178-84. Anderson AJ. 2000. Differential reliability of ${ }^{14} \mathrm{C}$ AMS 
ages of Rattus exulans bone gelatin in South Pacific prehistory. Journal of the Royal Society of New Zealand 30:243-61.

Anderson AJ. 2004. The age disconformity in AMS radiocarbon results on Rattus exulans bone. New Zealand Journal of Archaeology 24(2002):149-56.

Anderson AJ, Allingham BJ, Smith IWG, editors. 1996a. Shag River Mouth: The Archaeology of an Early Southern Maori Village. Research Papers in Archaeology and Natural History 27. Canberra: Australian National University. 294 p.

Anderson AJ, Smith IWG, Higham TFG. 1996b. Radiocarbon chronology. In: Anderson AJ, Allingham BJ Smith IWG, editors. Shag River Mouth: The Archaeology of an Early Southern Maori Village. Research Papers in Archaeology and Natural History 27. Canberra: Australian National University. p 60-9.

Beavan-Athfield N, Sparks RJ. 2001a. Dating of Rattus exulans and bird bone from Pleasant River (Otago, New Zealand): radiocarbon anomalies from diet Journal of the Royal Society of New Zealand 31(4): 801-9.

Beavan Athfield NR, McFadgen BG, Sparks RJ. 1999. Reliability of bone gelatin AMS dating: Rattus exulans and marine shell radiocarbon dates from Pauatahanui midden sites in Wellington, New Zealand. Radiocarbon 41(2):119-26.

Beavan-Athfield N, Sparks RJ. 2001b. Dating of Rattus exulans bone from Pleasant River (Otago, New Zealand): testing the effect of burial contamination Journal of the Royal Society of New Zealand 31(4): 795-800.

Bonsall C, Cook G, Hedges REM, Higham TFG, Pickard C, Radovanović I. 2004. Radiocarbon and stable isotope evidence of dietary change from the Mesolithic to the Middle Ages in the Iron Gates: new results from Lepenski Vir. Radiocarbon 46(1):293-300.

Bronk Ramsey C. 2001. Development of the radiocarbon calibration program OxCal. Radiocarbon 43(2A): 355-63.

Bronk Ramsey C, Hedges REM. 1999. Hybrid ion sources: radiocarbon measurements from microgram to milligram. Nuclear Instruments and Methods in Physics Research B 123:539-45.

Bronk Ramsey C, Pettitt PB, Hedges REM, Hodgins GWL, Owen DC. 2000. Radiocarbon dates from the Oxford AMS system: Archaeometry datelist 30. Archaeometry 42:459-79.

Bronk Ramsey C, Higham TFG, Bowles A, Hedges R. 2004. Improvements to the pretreatment of bone at Oxford. Radiocarbon 46(1):155-63.

Cook GT, Bonsall C, Hedges REM, McSweeney K, Boroneant V, Pettitt PB. 2001. A freshwater diet-derived ${ }^{14} \mathrm{C}$ reservoir effect at the Stone Age sites in the Iron Gates gorge. Radiocarbon 43(2A):453-60.

Coplen TB. 1994. Reporting of stable hydrogen, carbon and oxygen isotopic abundances. Pure and Applied Chemistry 66:273-6.

DeNiro MJ, Weiner S. 1988. Chemical, enzymatic and spectroscopic characterisation of "collagen" and other organic fractions from prehistoric bones. Geochimica et Cosmochimica Acta 52:2197-206.

Higham TFG. 1993. Radiocarbon dating the prehistory of New Zealand [unpublished D.Phil dissertation]. Hamilton, New Zealand: University of Waikato.

Higham TFG, Hogg AG. 1997. Evidence for late Polynesian colonization of New Zealand: University of Waikato radiocarbon measurements. Radiocarbon 39(2):149-92.

Higham TFG, Petchey FP. 2000. On the reliability of rat bone for dating in New Zealand. Journal of the Royal Society of New Zealand 30(4):399-409.

Higham TFG, Anderson AJ, Jacomb C. 1999. Dating the first New Zealanders: the chronology of Wairau Bar. Antiquity 73:420-27.

Higham TFG, Bronk Ramsey C, Petchey FJ, Tompkins C, Taylor M. 2004a. New AMS radiocarbon determinations from Kokohuia, New Zealand. In: Higham T, Bronk Ramsey C, Owen C, editors. ${ }^{14} \mathrm{C}$ and Archaeology, Proceedings of the Fourth Symposium, Oxford 2002. Oxford: Oxbow Books. Oxford University School of Archaeology Monograph 62. p 135-51.

Higham TFG, Hedges REM, Anderson AJ, Bronk Ramsey C, Fankhauser B. 2004b. Problems associated with the AMS dating of small bone samples: the question of the arrival of Polynesian rats to New Zealand. Radiocarbon 46(1):207-18.

Holdaway RN. 1996. Arrival of rats in New Zealand. Nature 384:225-6.

Holdaway RN. 1999. A spatio-temporal model for the invasion of the New Zealand archipelago by the Pacific rat Rattus exulans. Journal of the Royal Society of New Zealand 29(2):91-105.

Lanting JN, van der Plicht J. 1998. Reservoir effects and apparent ${ }^{14} \mathrm{C}$ ages. Journal of Irish Archaeology 9: $151-65$.

McCormac FG, Reimer PJ, Hogg AG, Higham TFG, Baillie MGL, Palmer JG, Stuiver M. 2002. Calibration of the radiocarbon time scale for the Southern Hemisphere: AD 1850-950. Radiocarbon 44(3):641-51.

Morton J, Miller M. 1968. The New Zealand Sea Shore. London: Collins. $638 \mathrm{p}$.

Reimer PJ, Reimer RW. 2001. A marine reservoir correction database and on-line interface. Radiocarbon 43(2A):461-3.

Smith IWG, Anderson AJ. 1998. Radiocarbon dates from archaeological rat bones: the Pleasant River case. Archaeology in Oceania 33:88-91.

Stuart AJ, Kosintsev PA, Higham TFG, Lister AM. 2004. Pleistocene to Holocene extinction dynamics in giant deer and woolly mammoth. Nature 431:684-9.

Stuiver M, Reimer PJ, Braziunas TF. 1998. High-precision radiocarbon age calibration for terrestrial and marine samples. Radiocarbon 40(3):1127-51.

van Klinken GJ. 1999. Bone collagen quality indicators for palaeodietary and radiocarbon measurements. Journal of Archaeological Science 26:687-95. 